\title{
ENVIRONMENTAL AND SOCIOECONOMIC ASSESSMENT OF TEXTILE PRODUCTS CONSUMPTION IN BRAZIL - RELATIONSHIPS WITH INTERNATIONAL TRADE
}

\author{
Alessandra Maria Giacomin \\ University of São Paulo. Sustainability Graduate Program, PHD Student
}

Sérgio Almeida Pacca

University of São Paulo. Sustainability Graduate Program, Associate Professor

\begin{abstract}
Textile products drive a significant portion of the world economy, providing jobs, and being present in every aspect of our lives in all countries around the world. However, in its production, issues related to environmental and social pressures emerge. Taking into consideration the growing concern related to environmental and social impacts, it is necessary to address the issue of emissions generated indirectly by the sectors that supply the textile industry. This work has carried out an environmental and socioeconomic assessment of the consumption of textile products in Brazil, considering the relationship with international trade. The methodology used was the Multi-Regional Input-Output (MRIO) analysis, and the database used was Exiobase 3, for the year 2011. It was possible to conclude that most of the indirect impacts related to the textile industry are domestically generated. In the category of climate change and primary energy consumption, the sector that stood out was natural gas, with $51 \%$ of $\mathrm{CO}_{2}$ emissions and $33 \%$ of energy consumption. The largest share of indirect jobs is generated in the commercial sector with 34\%, and the largest number of indirect employees are male with medium skill level, which represents $33 \%$, followed by workers from the vulnerable class (self-employed) with $27 \%$. Based on this analysis, it was possible to identify the greatest limitations related to socio-environmental aspects and the possible solutions to be adopted for this sector.
\end{abstract}

Key words: Textile industry, Analysis of textile products, Environmental and social analysis. Multi-Regional Input-Output analysis. 


\section{Evaluación ambiental y socioeconómica del consumo de productos textiles en Brasil: relaciones con el comercio internacional}

Resumen: Los productos textiles impulsan una parte importante de la economía mundial, proporcionan empleos, están presentes en todos los aspectos de nuestras vidas y en todos los países del mundo. No obstante, en su producción, surgen problemas relacionados con las presiones ambientales y sociales. Considerando la creciente preocupación relacionada con los impactos ambientales y sociales, es necesario abordar el tema de las emisiones generadas indirectamente por los sectores que abastecen la industria textil. El objetivo de este trabajo fue realizar una evaluación ambiental y socioeconómica del consumo de productos textiles en Brasil, tomando en cuenta la relación con el comercio internacional. La metodología utilizada fue el análisis de entrada-salida multiregional (MRIO), y la base de datos utilizada fue Exiobase 3, para el año 2011. Se pudo concluir que la mayoría de impactos indirectos relacionados con la industria textil son generados domésticamente. En la categoría de cambio climático y consumo de energía primaria, el sector que más destacó fue el gas natural, con $51 \%$ de las emisiones de $\mathrm{CO}_{2}$ y 33\% del consumo de energía. La mayor proporción de empleos indirectos se genera en el sector comercial con 34\%, y la mayor cantidad de empleados indirectos son hombres y tienen un nivel de habilidad medio con 33\%, seguidos por trabajadores de la clase vulnerable con $27 \%$. Basándose en este análisis, se identificaron cuáles son las mayores limitaciones relacionadas con los aspectos socioambientales, así como posibles soluciones a implementar para este sector.

Palabras clave: industria textil, análisis de productos textiles, análisis ambiental y social, análisis de entradas y salidas multiregionales. 


\section{Alessandra Maria Giacomin}

PHD student in the Sustainability Graduate Program at the University of Sao Paulo in Brazil, researcher in the area of global systems modeling and its effects on consumption, focusing on environmental and socioeconomic results (Extended Multi-Regional Analysis of Input and Output), with particular consideration in the consumption and trade of textiles.

Email: alessandra.giacomin@gmail.com

https://orcid.org/0000-0002-5861-9952

\section{Sergio Almeida Pacca}

Associate professor in the undergraduate program in Environmental Management at the School of Arts, Sciences, and Humanities (EACH) at the University of São Paulo (USP), and in the graduate program in Sustainability (PPGS-USP), Researcher in the areas of energy, sustainability, global climate change, life cycle assessment (LCA), and industrial ecology.

Email: spacca@usp.br

https://orcid.org/0000-0001-7609-5139 


\section{Introduction}

\subsection{Globalization and the Textile}

International trade allows world society to exchange not only goods and commodities, but also experiences and services. This globalization process and the opening of markets made possible many technological leaps and sharing of knowledge and information. With production chains spread all over the world, we see a new division of labor, where resource extraction, management, production, and marketing usually takes place in totally different places on the planet (Murray et al. 2018).

In this way, international trade is responsible for favoring the exchange of products, between countries with different resources and also, it is a determining agent to outline the industrial structure of a country and this affects several environmental aspects, such as the consumption of energy, greenhouse gas (GHG) emissions, mainly $\mathrm{CO}_{2}$ (carbon dioxide) and social pressures related to job creation. Due to this increase in global trade, we face environmental and social crises, where developed countries benefit from the import of resourceintensive, energy and carbon-based primary goods from the poorest parts of the world, especially from emerging nations. Currently, most of the world's pollution is released in regions far from large centers where industrialized goods are consumed (Wiedmann \& Lenzen 2018).

Therefore, for an understanding of resource efficiency, from a consumption perspective, that considers, the impacts in the upstream supply chains, there is a need to assess the environmental and social pressures, for instance, related to the jobs, embodied in trade. This demand requires a consumption-based approach, which helps to avoid gaps in sustainability assessments (Wood et al. 2018).

Among the global supply chains, textile products stand out, they are present in every aspect of our lives, as well as in all developed countries, even those with less relative economic development, moving a large portion of economies worldwide, providing great absorption of labor and determining consumption habits and behaviors in society (Ghisellini et al. 2016).

The textile and clothing sector is one of the most traditional and complex industrial and commercial sectors in the world, with a long supply chain, consisting of large economic sectors, which begins with obtaining and producing fibers and filaments, including spinning, weaving, knitting, finishing and clothing manufacturing, until it reaches distribution to final consumers, through various trading 
paths (CNI 2017). These processes depend on large quantities of lowcost materials, as well as easy access to water, energy and cheap labor (Ghisellini et al. 2016).

\subsection{Brazilian Textile Industry}

Brazil is positioned among the five largest textile suppliers in the world, with sales of US\$ 48 billion in 2018, (ABIT 2019). The Brazilian textile and clothing industry are valued at US 797 billion in global value, according to estimates from the World Trade Organization (WTO 2015).

When measuring the size and potential of the national consumer market, it is clear that Brazil could be a major importer of raw materials. However, since it has a vertical chain whose production is mainly focused on domestic supply, the country occupies only the 25 th position among those that import most, with a $0.8 \%$ share in imported value (IEMI 2016).

According to the World Integrated Trade Solution (WITS 2018), the countries that most import textiles to Brazil are: China US\$ 2.9 billion, India US\$ 501 million, Indonesia US\$250 million, Bangladesh US\$202 million and the United States US\$180 million. The Brazil's largest export trading partners are: China US\$ 522 million, Indonesia US\$ 249 million, Vietnam US\$244 million, Argentina US\$ 221 million and Bangladesh US\$ 156 million, for the year 2018.

Brazil is the largest complete textile chain in the western hemisphere, the industry that has been in the country for almost 200 years, covers everything from the production of fibers, such as cotton plantation, to fashion shows, including spinning, weaving, processing, clothing and strong retail (ABIT 2019).

Currently, the textile and clothing sector has more than 25 thousand production companies (formal), in addition to approximately 150 thousand points of sale, including specialized stores, wholesale centers, mall centers and department stores, present in the 27 Brazilian states. In 2018, US\$ 1 billion were invested in the sector. In the same year, the average production of clothing reached the margin of 8.9 billion pieces and the average textile production has 1.2 million tons (ABIT 2019).

Annually, in the textile sector, US\$ 6 billion is spent on salaries, US\$ 910 million is invested in modernization and expansion of production capacity, of which US $\$ 500$ million is invested in machinery and equipment, and US\$ 4.6 billion is spent on taxes (CNI 2017). In this regard, the commercial and industrial textile and clothing sectors have enormous social and economic relevance for Brazil.

Regarding the production of natural fibers, mainly cotton, Brazil is positioned as the fifth largest producer in the world, the third largest exporter and the ninth largest consumer. The Gross Value of Production (VBP), in 2018, was US\$ 9.5 billion, being the fourth most important crop in Brazilian agriculture, after soy, sugar cane and corn. It represents $9 \%$ in relation to the VBP of the crops above mentioned and $6 \%$ in relation to the VBP of agricultural production (Severino et al. 2019). 


\subsection{Social Impacts}

As the second largest employer in the Brazilian industry, the textile and clothing sector is second only to the food and beverage industry together. There are approximately 1.5 million direct jobs, representing $17 \%$ of the total workers in the manufacturing industry. The sector is also recognized as the second largest generator of the first job and represents $16 \%$ of jobs and $5 \%$ of the turnover of the Transformation Industry (ABIT 2019). This demonstrates the social relevance of this industry for Brazil, however, these data do not include informal workers in the segment.

Furthermore, if we look at the textile chain from a global perspective, we can see that, in the last 30 years, it has lifted many people from less-favored countries out of poverty, but it has also created concerns about labor abuse in countries that do not have strong labor representation. This ranges from overwork, gender discrimination, child labor and unsafe working conditions (Roos et al. 2017).

These countries and industries become net exporters of labor, where their own workers do not directly benefit from global trade, either financially, for reasons related to health or well-being, or for social justice. Alternatively, the workforce will move following the demand, creating a group of people who often work in some of the worst conditions in developing countries (Schmidt et al. 2019).

In such cases, a systemic aspect of the problem is that supply chains are global and complex; thus, it is difficult to know exactly where the clothes we wear are being produced. The long supply chain among buyer, trader, and manufacturer, isolates the management of distant workplaces; it is challenging to implement better conditions for clothing production, even if requested by customers (Ross et al. 2017).

The total estimate of the number of people working in the textile sector (direct and indirect), is extremely difficult to obtain, due to the number of small companies and subcontractors active in the area and the difficulty of establishing limits between sectors. The sector employs from farmers who cultivate natural fibers to highly qualified chemical engineers in the manufacture of synthetic fibers (Allwood et al. 2015).

In Brazil, according to data from the Departamento Intersindical de Estatística e Estudos Socioeconômicos (DIEESE 2014), just over half of the workers working in the textile and clothing sector have a formal contract, 2.6 million people are employed in the sector, but only 1.5 million belong to the formal sector. A good part of these numbers is due to the significant use of home work done by companies that outsource production steps, in addition to other categories such as informal labor from immigrants without citizenship, subcontracts in the production chain in clandestine workshops, and street traders at the end of the market chain. Besides the lack of compliance with labor legislation, informality is responsible for the lowest wages - the average salary of the informal clothing worker corresponds to just over half the salary of a formal worker (CNTV 2015). 


\subsection{Environmental Impacts}

Despite the positive relevance of the textile sector to the economy, it has harmful impacts on the environment and society, which extend across the entire production chain, from growing fibers to marketing products.

The growing concern of society with the impact of industrial activities on natural resources, associated with the water and energy crisis and the global problems of waste, climate change, among others, has increased the concern regarding consumption (CNI 2017). The wide range of applications and, consequently, the countless processes by which a textile product is likely to go through its manufacture, demonstrates the variety and complexity of this productive and commercial chain.

Activities in the textile production and commercial process constitute significant sources of primary energy consumption, blue water ${ }^{1}$ consumption, GHG emissions and air pollutants, included from the process of obtaining the fibers, to the commercialization and post-consumption (CAIXA 2018).

In addition, the textile chain indirectly depends on various inputs derived from other productive sectors, generating emissions and indirect consumption from other sectors of the economy, such as the fossil fuel sector for the production of synthetic polyester fibers, which are highly polluting and are directly linked to high GHG emissions (Peters et al. 2014).

Still, with regard specifically to the $\mathrm{CO}_{2}$ emissions of the textile and clothing industry, a study carried out in 2015 by the National Confederation of Industry (CNI 2017), called «Low Carbon Corporate Strategies - Textile and Clothing Sector», found that the sector has a share of $1.60 \%$ of the $\mathrm{CO}_{2}$ emissions of the national industry, without taking into account the services and indirect activities not controlled by the industry.

The use of limited resources is another fundamental challenge for the sustainability of the textile and clothing chain. The sector demands large amounts of energy for its production process. Data from the National Energy Balance (EPE 2019), show that the main sources of energy used by the textile sector are, respectively, electricity, natural gas and firewood.

The excessive consumption of natural resources to produce textile artifacts in developed and emerging countries leads to serious environmental and social consequences. In this regard, considering the globalization of markets, in which the textile sector is embedded, the issue of local and displaced emissions resulting from trade between countries must be examined. Therefore, the objective of this study is to evaluate the Brazilian textile supply chain and its environmental and socioeconomic impacts, from the perspective of the domestic consumption. 


\section{Methods and Data}

This research is based on multi-regional input output analysis (MRIO), which uses physical input and output tables that record material flows at various levels of detail for the economy, by economic activity and final demand category at a global level. The strength of MRIO analysis, as a methodology for assessing environmental and social impact, is its ability to track the impacts of products across the supply chain and assign impacts at different stages of production to end consumers (Moran \& Wood 2014). This allows MRIO analysis to track international supply chains that are increasingly fragmented between primary, secondary and tertiary producers, to provide a more complete picture of the impacts of nations' final consumption (Stadler et al. 2018).

Improvements in input output methodologies make analysis increasingly relevant to industrial ecology and more and more practice in this field. Several environmentally and multiregional expanded entry and exit data banks, covering the global economy, are available. Studies using MRIO databases are used to analyze problems of concern about energy consumption, $\mathrm{CO}_{2}$ emissions among others (Wiedmann \& Lenzen 2018).

For this type of analysis, detailed global databases are used, such as EXIOBASE, used in this study, these have the great advantage of being consistent and complete, and can follow supply chains at a global level, thus being suitable to analyze a wide range of issues related to environmental and social impacts, trade and economic globalization, in a consistent structure. The set of integrated and detailed environmental and economic data make it the appropriate basis for conceiving new policies (Tukker et al. 2016).

For this research, the EXIOBASE 3 database, which relies on multi-regional input and output data, was used to assess how international trade allocates the environmental pressure of textile products. Environmental pressures for energy use, global warming potential and social pressures related to work were analyzed, referring to the 2011 international accounts.

EXIOBASE consists of a detailed and multiregional global model for the use of environmental supplies (MR-SUT- multi-regional supply use tables) combined with an input and output table (MR-IOT - multi-regional input output tables). This was developed by harmonizing and detailing supply use tables for 44 countries, plus 5 regions in the rest of the world $\left(\mathrm{ROW}^{2}\right)$, estimating emissions and resource extractions for each economic sector. Subsequently, the country's supply use tables were linked via trade, creating an MR-SUT and producing an MR-IOT from that. The MR-IOT table can be used to analyze the environmental and social impacts associated with the final consumption of products from specific sectors.

For this study specifically, the Brazilian textile manufacturing sector was analyzed. From this, an evaluation was carried out to investigate which sectors in transactions with resident units or have other economic ties with these units (OECD 2001). 
the Brazilian textile chain generates demand.

It was found that, to produce $€ 1$ (one euro) in goods, the Brazilian textile sector requires 54 cents from other sectors of the economy. In total, 3,981 sectors represented by 44 countries, including Brazil itself, plus five other rest of the world (ROW) regions are part of the supply chain.

However, the analysis of representativeness shows that $95 \%$ of the Brazilian textile monetary demand is attributed to only 46 of these sectors. Thus, the analysis of environmental and social impact of this study was based only on these 46 sectors, including 9 countries, in descending order, China, ROW America, the USA, India, Taiwan, Indonesia, ROW middle east, Row Asia and Pacific and Ireland, in addition to Brazil.

The categories of environmental and social impact analyzed were: GHG Global warming potential (GWP100) - $\mathrm{CO}_{2}$ eq.; Total primary energy use - MJ and Social Footprint - Total employment (hours/gender and skill level).

Finally, the total demand induced impacts of the Brazilian textile sector were accounted for according to the equation below, which determines the sum of the impacts that each sector produces per euro, multiplied by its share in Brazilian textile input.

$$
E=\sum\left(e_{i} \times s_{i}\right)
$$

Where:

$\boldsymbol{E}=$ total environmental/social impact due to Brazilian textile consumption.

$\boldsymbol{i}=$ sector in the Brazilian textile supply chain.

$\boldsymbol{e}=$ environmental or social impact of sector's $\boldsymbol{i}$ supply chain.

$\boldsymbol{s}=$ share in the Brazilian textile's supply chain.

\section{Results}

In the category of climate change, the textile sector releases $102 \mathrm{gCO}_{2}$ eq/euro. As seen in Figure 1, among the sectors that participate in the emission induced by the textile supply chain, the main one is the natural gas sector, with a $51 \%$ share, followed by the commercial sector with $17 \%$, while other business services sector, has a share of $7 \%$. The textile sector itself contributes with only $4 \%$ of the total, and the chemical sector with 3\%. The remaining 18\% refers to other 40 sectors. 
Figure 1 - Share in total demand-based emission $\mathrm{CO}_{2}$ eq/euro

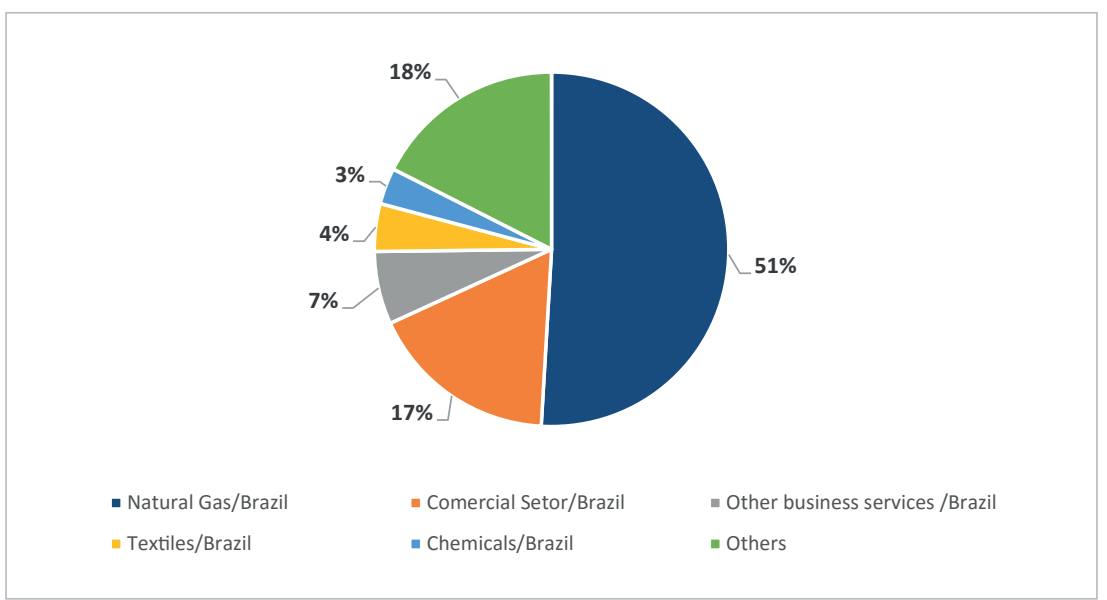

Prepared by the authors. Data source: Exiobase 3 - monetary (year 2011).

Regarding primary energy consumption, the textile sector consumes a total of 3.34 MJ/euro. According to Figure 2, the natural gas sector again has the largest share in the total with $33 \%$, followed by gas and diesel with $17 \%$. The chemical products sector has a $9 \%$ share, and heavy fuel oil and hydroelectricity are responsible for a $6 \%$ each. The textile sector itself presents a relatively low percentage, only $4 \%$, as well as the trade sector. The other 39 sectors together make up the remaining $20 \%$ share.

Figure 2 - Share in total energy consumption MJ/Euro

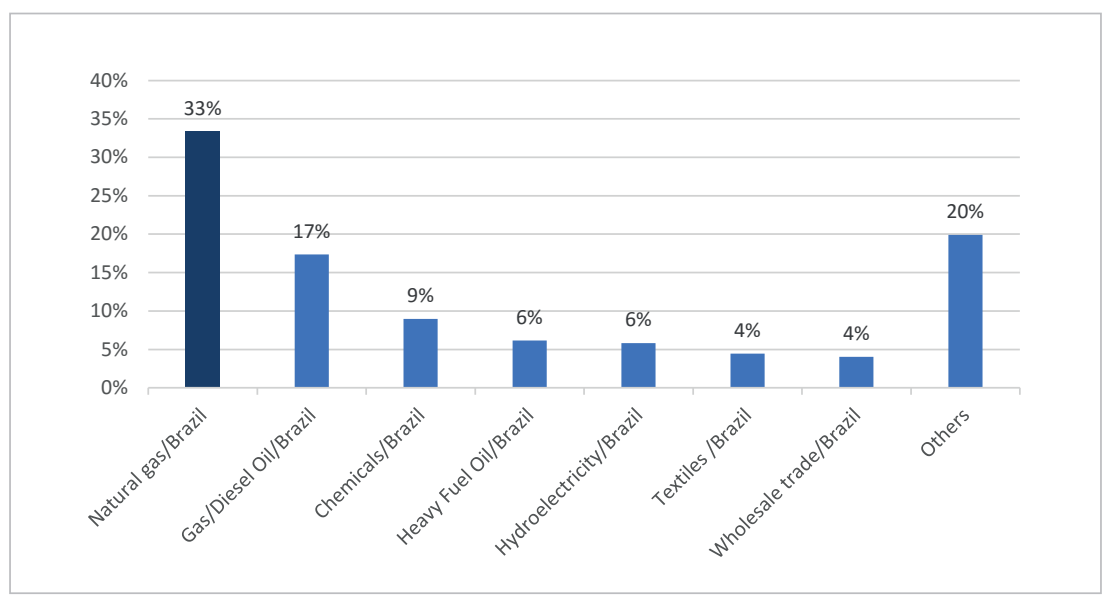

Prepared by the authors. Data source: Exiobase 3 - monetary (year 2011). 
Related to the social impact, the analysis showed that the textile sector generates approximately 4 minutes of employment per euro (Figure 3). The sector that generates more jobs due to the demand of the textile sector is the commercial sector (wholesale and retail), together with $35 \%$, followed by the textile sector itself, with $17 \%$, the natural fibers sector with $16 \%$, and other business services account for $13 \%$ and the remaining 42 sectors represent $19 \%$.

Figure 3- Distribution of Employment by sector

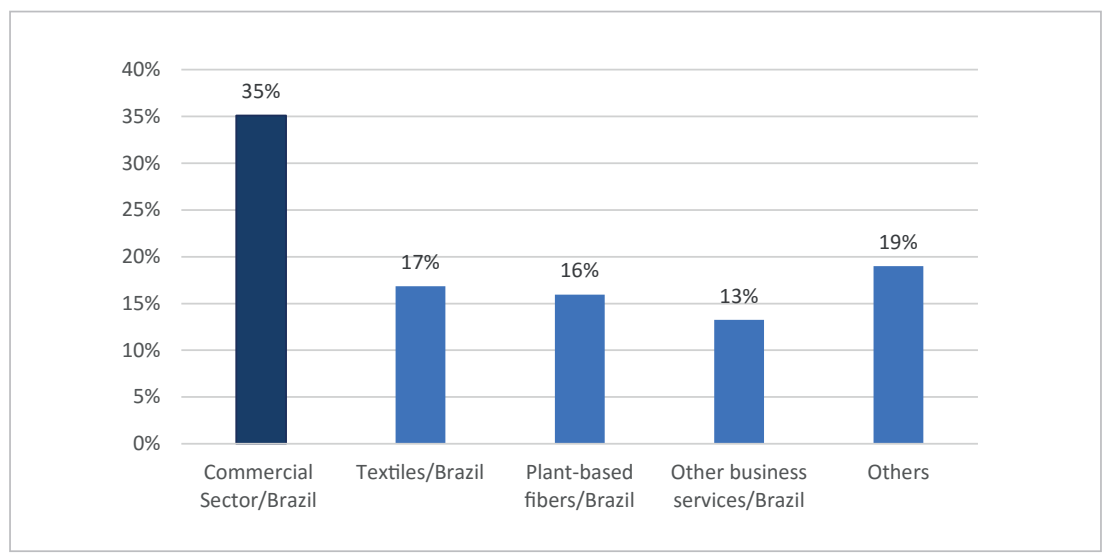

Prepared by the authors. Data source: Exiobase 3 - monetary (year 2011)

Still related to social impact, we analyzed the gender of workers and their skill level. The analysis has shown that $33 \%$ of the active workers are male and have an average skill level, in second place appear workers of the «vulnerable» class, without a formal employment contract (self-employed), with 27\%. Results are presented in Figure 4.

Figure 4 - Employment hours by gender and skill level

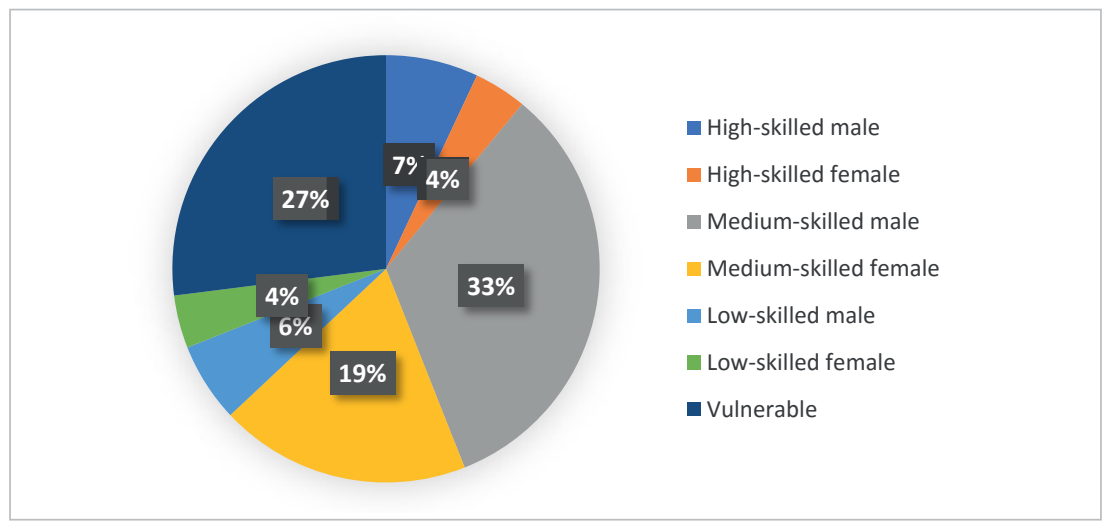

Prepared by the authors. Data source: Exiobase 3 - monetary (year 2011). 
Comparing the direct and indirect effects in the supply chain, we can see that the Brazilian sector emits: 2.9 times more $\mathrm{CO}_{2}$ eq and consumes 2.8 times more energy due to indirect inputs. However, in the jobs generation, the textile sector generates more jobs within the sector itself than in other sectors, 1.3 times more from the direct impacts, as can be seen in Figure 5 .

Figure 5 - Comparison of the direct and indirect impacts of demand from the Brazilian textile supply chain

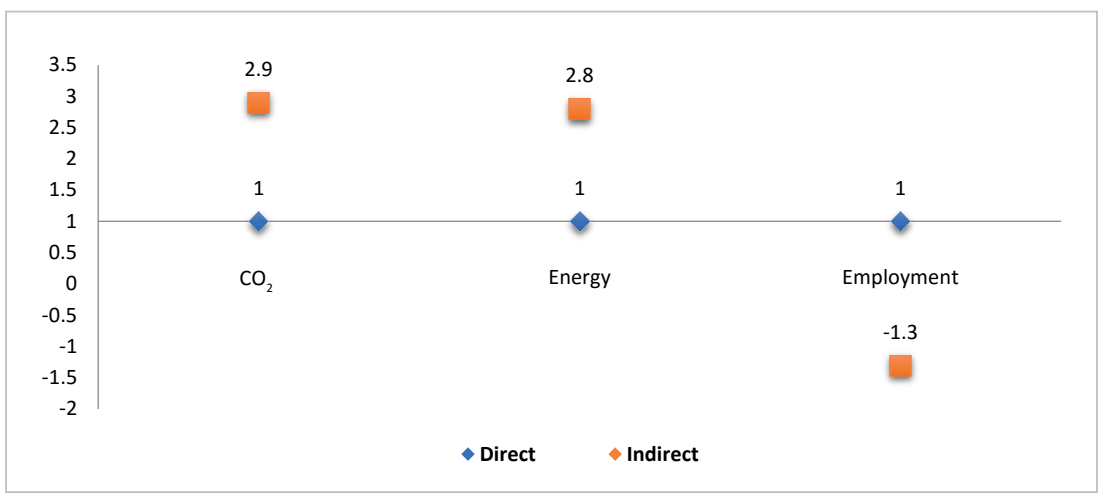

Prepared by the authors. Data source: Exiobase 3 - monetary (year 2011).

\section{Discussion and conclusions}

As we can see, the analysis of the demand shows that most of the indirect impacts generated by the demand of the textile chain are within the borders of Brazil itself, mainly for all categories. This is because the Brazilian textile chain is fully verticalized, covering all stages of production, and its production is mainly focused on internal supply (IEMI 2016).

According to data from the National Emissions Registry System from the Ministry of Science, Technology, and Innovations (MCTI 2020) and World Bank (2020) for the year 2011, the carbon intensity of the Brazilian economy was 284 $\mathrm{gCO}_{2}$ eq./real, equivalent to $122 \mathrm{gCO}_{2}$ eq./euro according to the exchange rate of the same year (Banco Central do Brasil 2010). It is possible to observe that the carbon intensity of the textile sector $\left(102 \mathrm{gCO}_{2}\right.$ eq./euro) is $16 \%$ lower than the average carbon intensity of the Brazilian economy.

The data indicate that the highest indirect GHG emissions and energy demand are generated by the natural gas sector, this results from being the second largest energy consumed in the textile sector after electricity (with the Brazilian electricity sector having a low emission factor, due to the fact that it is mostly generated from hydroelectricity). Furthermore, another relevant issue is that, in addition to direct consumption, natural gas is also associated with electricity 
consumption, since $9 \%$ of electricity generated in Brazil comes from energy plants powered by natural gas, according to the National Energy Balance (EPE 2019). Monitoring its consumption, prioritizing electrification based on renewable energy sources (solar, wind, biomass) and reducing the use of fossil fuels (diesel, gasoline, natural gas, mineral coal), should be a priority for the textile industry.

The sector that generates more jobs due to the demand from the textile sector is the commercial sector (wholesale and retail together). This is due to the fact that Brazil has a strong retail market, throughout the national territory there are approximately 150 thousand sales points of textile and clothing products, including specialized stores, wholesale centers, shopping centers and department stores (IEMI 2016).

The largest number of people employed, due to indirect demand, are men with an average level of skills, followed by workers from the «vulnerable» class. At this point, what calls our attention are the workers of the vulnerable class, that is, those who are not formally employed, considering that, in Brazil alone, there are 2.6 million workers in the textile sector, but less than half have a formal employment contract. Designing strategies that can face the challenges that informality imposes on working conditions is essential to make the textile industry more just and sustainable. Alternatively, the living conditions of workers with flexible employment agreements could be improved.

As we can see, the study shows that textile products have a high impact on the life cycle per euro and are strong candidates for resource efficiency improvements throughout their production cycles. There are several alternatives that can contribute to reducing the impacts of the textile chain, in relation to both environmental and social impacts, for example, the production of agroecological cotton, which is capable of restoring degraded areas and retaining carbon in the soil, contributing positively to the mitigation of climate change (Severino et al. 2019). Another relevant factor, which should be considered is the gradual replacement of energy consumption from fossil fuels with renewable energy, as well as the development of the circular economy within the sector; this would help to reduce global environmental and social footprints and improve sustainability textile (Roos et al. 2017). However, and above all, it is necessary to change the business models, which are currently based on exponential production and sales.

When combined with monetary input-output analysis, physical and environmental input and output analysis are particularly relevant to support structural adjustments based on the identification of bottlenecks along the supply chain.

Another important issue to be addressed is the increased awareness of consumers about the impacts generated by the products they buy. Producers exert impacts and control production methods, but consumer choice and demand drive production, so that responsibilities can be seen in both sides, and therefore, information regarding the complete supply chain must be shared among them.

Finally, we conclude that, for the political relevance of accounting for the social and environmental impacts of the textile chain, many improvements and new research approaches need to be studied. It is essential to quantitatively estimate consumption and resource flows at national and global levels. 
The analysis highlights implications for future policies targeting environmental and social goals, while fully considering the potential effects of international trade. We anticipate that our results can facilitate regulations, labeling of consumer products and sustainable certification of the textile supply chain.

\section{References}

ABIT (Associação Brasileira da Indústria Têxtil) (2019). Perfil do Setor. São Paulo. In: https://www.abit.org.br/cont/perfil-do-setor.

Allwood, J. M., Laursen, S. E., de Rodriguez, C. M., \& Bocken, N. M. (2015). Well dressed? The present and future sustainability of clothing and textiles in the United Kingdom. Journal of the Home Economics Institute of Australia, 22(1): 42.

BCB (Banco Central do Brasil) (2020). Taxas de Câmbio. In. dadosabertos. bcb.gov.br/dataset/taxas-de-cambio-todos-os-boletins-diarios

CNI (Confederação Nacional da Indústria) (2017). O setor têxtil e de confecção e os desafios da sustentabilidade. Associação Brasileira da Indústria Têxtil e de Confecção - Brasília, 108 p.

CNTV (Confederação Nacional dos Trabalhadores nas Indústrias do Setor Têxtil) (2015). Vestuário. Indicadores Socioeconômicos - Setor Têxtil, Vestuário, Couro e Calçados. São Paulo, 2014. In: cntvcut.org.br/system/uploads/action_file_ version/cc932da2008ff251e7d27e97544cf0de/file/revista-cntv-baixa.pdf.

DIEESE (Departamento Intersindical de Estatística e Estudos Socioeconômicos) (2014). Micro, serviço brasileiro de apoio às pequenas empresas. Anuário do trabalho na micro e pequena empresa. In. https://goo.gl/ XQgRxG

EPE (Empresa de Pesquisa Energética) (2019). Balanço Energético Nacional: Relatório síntese, ano base 2018. Rio de Janeiro: Ministério de Minas e Energia.

EXIOBASE-Extended Multi-Regional Input-Output-EXIOBASE 3. (2020). In: exiobase.eu/index.php/data-download/exiobase3mon

CAIXA (Gerência nacional de sustentabilidade e responsabilidade socioambiental da Caixa Econômica Federal) (2018). Guia de diretrizes socioambientais indústria têxtil. In: www.caixa.gov.br/Downloads/GuiasSocioambientais-Caixa/GUIA_Textil.pdf

Ghisellini, P., Cialani, C., \& Ulgiati, S. (2016). A review on circular economy: the expected transition to a balanced interplay of environmental and economic systems. Journal of Cleaner production, 114: 11-32.

IEMI (Industrial Marketing and Studies Institute) (2016). Relatório setorial da indústria têxtil brasileira, 15 (15). São Paulo.

MCTIC (Ministério da Ciência, Tecnologia, Inovações e Comunicações) (2020) Emissões de dióxido de carbono equivalente por setor. In: sirene.mctic.gov. br/portal/opencms/paineis/2018/08/24/Emissoes_em_dioxido_de_carbono_ equivalente_por_setor.html 
Moran, D., \& Wood, R. (2014). Convergence between the Eora, WIOD, EXIOBASE, and Open EU's consumption-based carbon accounts. Economic Systems Research, 26(3), 245-261.

Murray, J., Malik, A., \& Geschke, A. (Eds.). (2018). The social effects of global trade. Quantifying impacts using multi-regional input-output analysis. Pan Stanford Publishing Pte. Ltd.

OECD (Organization for Economic Cooperation and Development) (2001) Glossary of statistical Terms. In. stats.oecd.org/glossary/detail.asp?ID=2338.

Peters, G. M., Granberg, H., \& Sweet, S. (2014). The role of science and technology in sustainable fashion. Routlegde Handbook of Sustainability and Fashion; Fletcher, K., Tham, M., Eds.

Roos, S., Sandin, G., Zamani, B., Peters, G., \& Svanström, M. (2017). Will clothing be sustainable? Clarifying sustainable fashion. In Textiles and clothing sustainability (pp. 1-45). Springer, Singapore.

Schmidt, S., Södersten, C. J., Wiebe, K., Simas, M., Palm, V., \& Wood, R. (2019). Understanding GHG emissions from Swedish consumption-Current challenges in reaching the generational goal. Journal of cleaner production, 212: 428-437.

Severino, L., Rodrigues, S., Chitarra, L., de Lima Filho, J. R., Contini, E., Mota, M.,... \& Aragão, A. (2019). Algodão-Parte 01: Caracterização e desafios tecnológicos. Embrapa Algodão-Nota Técnica/Nota Científica (ALICE).

Stadler, K., Wood, R., Bulavskaya, T., Södersten, C. J., Simas, M., Schmidt, S., ... \& Giljum, S. (2018). EXIOBASE 3: Developing a time series of detailed environmentally extended multi-regional input-output tables. Journal of Industrial Ecology, 22(3): 502-515.

Tukker, A., Bulavskaya, T., Giljum, S., De Koning, A., Lutter, S., Simas, M., ... \& Wood, R. (2014). The global resource footprint of nations. Carbon, water, land and materials embodied in trade and final consumption calculated with EXIOBASE, 2(8).

Tukker, A., Bulavskaya, T., Giljum, S., de Koning, A., Lutter, S., Simas, M., \& Wood, R. (2016). Environmental and resource footprints in a global context: Europe's structural deficit in resource endowments. Global Environmental Change, 40: 171-181.

Wiedmann, T., \& Lenzen, M. (2018). Environmental and social footprints of international trade. Nature Geoscience, 11 (5): 314-321.

Wood, R., Stadler, K., Simas, M., Bulavskaya, T., Giljum, S., Lutter, S., \& Tukker, A. (2018). Growth in environmental footprints and environmental impacts embodied in trade: resource efficiency indicators from EXIOBASE3. Journal of Industrial Ecology, 22(3): 553-564.

World Bank (2020). GDP growth (annual \%) - Brazil. In. https://data. worldbank.org/indicator/NY.GDP.MKTP.KD.ZG?locations=BR

World Integrated Trade Solutions (WITS) (2018). Brazil Trade at a Glance: Most Recent Values. In wits.worldbank.org/CountryProfile/en/Country/BRA/ Year/2018/TradeFlow/EXPIMP/Partner/by-country/Product/50-63_TextCloth

World Trade Organization (WTO) (2015). Textile: back in the mainstream. In www.wto.org/english/tratop_e/texti_e/texti_e.htm 